\title{
Dentists' Knowledge, Attitudes and Practices Regarding Hepatitis B, C and Human Immunodeficiency Virus/ Acquired Immunodeficiency Syndrome in Northeast Part of Rajasthan
}

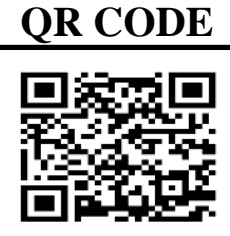

OM PRAKASH YADAV*1, DEEPAK YADAV ${ }^{2}$, AISHWARYA JOSHI ${ }^{3}$, SWATI JOSHI ASOPA4 ${ }^{4}$, NAIEM AHMED ${ }^{5}$, MANJU PANWAR

INTRODUCTION: Healthcare professionals including surgeons, dentists and paramedical personnel's belong to high risk group of transmitting blood borne pathogens. Keeping this in view a study was proposed to assess the Knowledge, Attitude, and Practices (KAP) of dental professionals towards different viral diseases in northeast part of Rajasthan.

MATERIALS AND METHOD: A cross-sectional, descriptive study was conducted among 500 randomly selected dentists in Jaipur district. Questions regarding KAP of hepatitis B (HBV), Hepatitis C (HCV) and Human immunodeficiency virus (HIV) / Acquired immunodeficiency syndrome (AIDS) were included in the questionnaire. Statistical analysis was done through SPSS Ver. 20.0. software using chi-square test, independent t-test and analysis of variance (ANOVA) to evaluate the differences between parameters.

RESULTS: The result indicates that the majority of the study subjects $(60 \%)$ were female. The mean (+Standard Deviation) for age and work experience was $35.5+8.85$ and $5.6+8.76$ respectively. The mean value of KAP was $38.4+3.23,21.5+4.34$ and $23.05+5.67$ respectively. It was observed that knowledge regarding HBV, HCV and HIV/AIDS was statistically significant with work experience ( $>10$ Years; p<0.001), year of graduation (after 2006; p<0.001). Attitude of study subjects for HBV, HCV and HIV/AIDS was significantly inclined by age group $(<30$ years: $\mathrm{P}=0.011)$, work experience $(\geq 10$ years: $\mathrm{P}<0.001$ ), and place of work (dental clinic: $\mathrm{P}=0.013)$.

CONCLUSIONS: The observations of the study highlighted a reasonable level of knowledge and attitude of dental practitioners for $\mathrm{HBV}, \mathrm{HCV}$ and HIV/AIDS infections. However there is a need of improvement in the knowledge level which can alter their attitude and practice towards patients with HBV, HCV and HIV/AIDS infections.

KEYWORDS: Knowledge, Attitude, Practice, Hepatitis B, Hepatitis C, HIV/AIDS, Dentists

\section{INTRODUCTION}

According to World Health Organisation (WHO), 36.9 million people living with HIV (PLHIV) worldwide. ${ }^{1}$ In HIV epidemic countries' list, India stood third in the world. In India, 2.1 million population living with HIV., ${ }^{2,3}$ Rajasthan contribute $3 \%$ of total PLHIV in India. ${ }^{4}$ It is estimated that $7.0 \%$ patients were found positive for HBsAg, $36.75 \%$ for anti-HCV, $0.9 \%$ for HIV antibody and $0.3 \%$ had both HBV and HCV infection. These viruses have the ability of transmission by blood and blood products. 5

HIV, HBV and HCV infections are a threat to professionals and paramedical staff. According to WHO report, it is estimated that 2 million injuries result in around 66000,16000 and 1000 infections of HBV, HCV and HIV in 35 million medical workers every year. ${ }^{6-7}$ According to WHO report, injury through sharp instruments and needles are 4 per health care worker $(\mathrm{HCW})$ in Asia and this is an alarming situation. ${ }^{8-10}$ Dentist and other health care workers are at a great risk of infection of HBV, HCV and HIV/AIDS. Dental professionals are at a higher risk of getting different infections through saliva and blood. ${ }^{11-12}$

There is a increasing trend of blood borne infections mostly HIV/AIDS \& HBV, and issue related to financial and psychological aspect towards job related injuries, it is highly desirable to enforced a effective and urgent training for healthcare professionals. The training module should include various ways of transmission, pathogenesis of microorganisms, prevention \& control measures, and proper attention in response to injuries by needle and sharps. ${ }^{13-14}$

Limited data on high risk groups is the prime obstacle which slows down the preventive and monitoring procedure. It is necessary to highlight the core knowledge of healthcare workers especially dentist on this issue so that it can be taken as a tool of policy making.

There are many studies globally and in India suggested that proper infection control measures are not undertaken by dentals hospitals. ${ }^{15-18}$ Although there 
are several studies has been undertaken to assess the KAP of dentist towards HBV, HCV and HIV/AIDS in India but there is very limited data available on this issue in northeast part of Rajasthan.

\section{MATERIAL AND METHODS}

A cross-sectional, descriptive study was conducted among 500 public and private dental practitioners in Jaipur district, Rajasthan. A predesigned, pre-validated, questionnaire was adopted for the study. ${ }^{19-22}$ Questionnaire covered details of demography, work experience, year of graduation and work place of dentist and questions of KAP on HBV, HCV and HIV/AIDS infections. The study protocol was approved by ethical committee of a private dental college in Jaipur. Frequency distribution, descriptive statistics were used to analyze the data.

The interpretations of scores were given as poor, medium and good. More than 12 correct responses were defined as good knowledge, 8-12 correction answers were considered as average knowledge and less than 8 replies were known as poor knowledge. The attitude was classified as negative (scores 13 to 21), neutral (scores 22 to 30) and positive attitude (scores 31 to 39). Practice was defined as poor (scores 18 to 36 ), moderate (scores 37 to 54) and good practice (scores 55 to 72 ).

For data analysis, chi-square test, independent t-test and ANOVA test were applied to evaluate differences between the groups using SPSS ver. 20.0 and $p$ value was considered at 0.05 as level of significance.

\section{RESULTS}

Most of the dentist showed the good knowledge of different methods of spreading HBV, $\mathrm{HCV}$ and HIV/AIDS and their treatment modality. About postexposure HIV/AIDS prophylaxis after needle stick injury and HBV mostly spread via sexual contact or blood, $83.96 \%$ \& $79.25 \%$ dentist replied correctly.

Knowledge about ways of transmission of HIV/AIDS like mother to child and air or waterborne was $96.26 \%$ \& $89.06 \%$ respectively. Additionally, dentist's perception on transmission of infection via social activities such as kissing, handshake, and sharing common glasses was $80.19 \%$. The minimum scores of knowledge were on prevention \& vaccination of $\mathrm{HBV}$ after needle stick injuries, as only $11.32 \%$ (Table 1 ).

In addition, the majority of subjects inclined positive attitudes towards HBV, HCV and HIV/AIDS. For example, risk of transmission of these viral diseases from patient to patient, patient to dental professional and dental professional to patient without using universal precautions was $90.07 \%, 92.46 \%$ and $79.24 \%$, respectively. Along with this, $65.09 \%$ of the subjects thought that patients with these viral diseases should receive dental treatment from special dental hospital. The majority of the subjects $75.85 \%$ \& $66.04 \%$ replied that all patients should be considered potentially infectious and dentists have a professional obligation to treat HIV/AIDS positive patients respectively. (Table 2)

Table 3 presents the practice scores of dentists. About $93.4 \%$ believed in using latex gloves, and $91.5 \%$ believed in sterilization by dry heat and autoclave equipment. The majority of the subjects $(79.25 \%)$ using protective glasses and wash them regularly. Around $77 \%$ dentists use gown for their patient.

\section{DISCUSSION}

KAP level of dental professionals towards HBV, HCV and HIV/AIDS was moderate. It is seen that dental professionals who was less than 30 year, had vast work experience and who passed their graduation after 2006, showed better level of knowledge and attitude. In addition to it, knowledge and attitude of dental professionals working in private hospitals were had better score with other counterparts.

Knowledge: A study conducted by Rabiee et al. ${ }^{23}$ showed that $67 \%$ and $30 \%$ of the dental professionals had poor and moderate level of knowledge regarding transmission and methods of treatment of HIV/AIDS, $\mathrm{HBV}$, and HCV infections. If exposure occurred to HCV patients, the first and foremost action is to put pressure on the wound area, clean the wound area with water and try to eliminate the infection. Study conducted by Kakouei et al. ${ }^{24}$ reflected that poor knowledge regarding sterilization can lead to spread of infection. A study done by Askarian et al. ${ }^{20}$ also felt that treatment of HIV/AIDS cases are accepted by dentists but a high fear of spreading HIV to them or their patients was seen.

A study conducted by Leon et al. ${ }^{25}$ found that $93 \%$ of the dentists had very limited knowledge towards the universal precautions. In addition to it, Hammond et al. ${ }^{26}$ also observed that only $16 \%$ of the dental professional used universal precaution guidelines. The majority of infected cases in dental setting are random and prevention can be taken by applying attention to 


\begin{tabular}{|c|c|c|c|}
\hline QUESTIONS & $\begin{array}{c}\text { Yes } \\
\mathrm{N}(\%)\end{array}$ & $\begin{array}{l}\text { Don't Know } \\
\text { N }(\%)\end{array}$ & $\begin{array}{c}\text { No } \\
\text { N }(\%)\end{array}$ \\
\hline Can HIV/AIDS be transmitted from mother to child? & $510(96.23)$ & $1(0.19)$ & $19(3 \cdot 58)$ \\
\hline Can HIV/AIDS be transmitted through air or water? & $55(10.38)$ & $3(0.57)$ & $472(89.06)$ \\
\hline $\begin{array}{l}\text { Can HIV/AIDS be transmitted through social contact } \\
\text { (shaking hands, kissing, sharing glasses, clothes, etc.)? }\end{array}$ & $100(18.87)$ & $5(0.94)$ & $425(80.19)$ \\
\hline Can HIV/AIDS be transmitted through saliva? & $375(70.75)$ & $5(0.94)$ & $150(28.30)$ \\
\hline $\begin{array}{l}\text { Can HIV/AIDS be completely cured with antiretroviral } \\
\text { therapy? }\end{array}$ & $425(80.19)$ & $6(1.13)$ & $99(18.68)$ \\
\hline $\begin{array}{l}\text { Can antiviral medications (e.g. acyclovir, amantadine) } \\
\text { be used to treat HIV/AIDS? }\end{array}$ & $160(30.19)$ & $30(5.66)$ & $340(64.15)$ \\
\hline Can patients with HIV/AIDS donate blood? & $65(12.26)$ & $14(2.64)$ & $451(85.09)$ \\
\hline $\begin{array}{l}\text { Is post-exposure HIV/AIDS prophylaxis recommended } \\
\text { after a needle stick injury? }\end{array}$ & $445(83.96)$ & $16(3.02)$ & $69(13.02)$ \\
\hline Can HIV infection develop into AIDS within a year? & $350(66.04)$ & $13(2.45)$ & $167(31.51)$ \\
\hline $\begin{array}{l}\text { Is the risk of HIV/AIDS infection after a needle stick } \\
\text { about } 50-75 \% \text { ? }\end{array}$ & $110(20.75)$ & $10(1.89)$ & $410(77 \cdot 36)$ \\
\hline $\begin{array}{l}\text { Is HBV mainly transmitted through sexual contact or } \\
\text { blood? }\end{array}$ & $420(79.25)$ & $15(2.83)$ & $95(17.92)$ \\
\hline Is a vaccine for HCV available? & $350(66.04)$ & $13(2.45)$ & $167(31.51)$ \\
\hline $\begin{array}{l}\text { Should individuals with } \mathrm{HBV} \text { and } \mathrm{HCV} \text { infections } \\
\text { receive dental treatment in hospital? }\end{array}$ & $210(39.62)$ & $14(2.64)$ & $306(57 \cdot 74)$ \\
\hline $\begin{array}{l}\text { Is the risk of HCV infection after a needle stick about } \\
\qquad 10-20 \% \text { ? }\end{array}$ & $80(15.09)$ & $57(10.75)$ & $393(74.15)$ \\
\hline $\begin{array}{l}\text { Is vaccination against } \mathrm{HBV} \text { an efficient protection } \\
\text { against infection after an infected needle stick? }\end{array}$ & $60(11.32)$ & $25(4.72)$ & $445(83.96)$ \\
\hline $\begin{array}{l}\text { Is transmission after needle stick higher for HBV in } \\
\text { comparison with HIV/AIDS? }\end{array}$ & $280 \quad(52.83)$ & $32(6.04)$ & $218(41.13)$ \\
\hline
\end{tabular}

Table 1. Questions to Assess Knowledge About HBV, HCV, and HIV/AIDS Infections Among Dentists ( $\mathrm{n}=530)$

the guideline of infection control.

Attitude: A study conducted by Jafari et al. observed that poor level of knowledge and attitude of senior dental students for HIV/AIDS infection and advised inclusion of training courses so that knowledge and attitude can be promoted. ${ }^{27}$ A study conducted by Rabiee et al..$^{23}$ showed that $26.3 \%$ and $73 \%$ of dental professionals had a negative and positive attitude for having contact with HIV/AIDS patients respectively. In general, the positive attitude of dental professionals regarding treating patients with high-risk and more concern for their own health and risk of the spreading of virus to others were constant with the observations of past studies. ${ }^{23}$

Practice: On the basis of observation of the present study, it can be inferred that dentists of Jaipur district have a moderate practice regarding $\mathrm{HBV}, \mathrm{HCV}$ and
HIV/AIDS infections. A study conducted by Ajami et al. ${ }^{28}$ observed that $27 \%$ of the subjects showed poor practice, $60 \%$ reflect moderate, and $12 \%$ showed good practice towards HBV, HCV and HIV/AIDS infections. Saglam et al. conducted a study and found that $48.5 \%$ use gloves, whereas a study conducted by Burke observed $60 \% .^{29,30}$ Use of gloves is an essential protective method to prevent cross- contamination. Handling of dental instruments specially sharps can lead to high risk of cross-contamination through rupture in the glove or even a cut in the hand.

\section{CONCLUSION}

Dental professionals with a moderate level of knowledge towards HBV, HCV and HIV/AIDS infections were affected by their work experience and graduation year. Dental setting (private hospital and dental clinic) is mainly responsible for a Positive attitude for infected patients. The observation of the 


\begin{tabular}{|c|c|c|c|}
\hline QUESTIONS & $\begin{array}{l}\text { Agree } \\
\text { N }(\%)\end{array}$ & $\begin{array}{l}\text { Uncertain } \\
\mathbf{N}(\%)\end{array}$ & $\begin{array}{l}\text { Disagree } \\
\mathbf{N}(\%)\end{array}$ \\
\hline I would prefer not to treat patients who are HIV/AIDS positive. & $133(25.09)$ & $146(27.55)$ & $251(47 \cdot 36)$ \\
\hline $\begin{array}{c}\text { Dentists should have the opportunity to refuse to treat } \\
\text { patients with HBV, HCV and HIV/AIDS. }\end{array}$ & $122(23.02)$ & $56(10.57)$ & $352(66.42)$ \\
\hline $\begin{array}{l}\text { Patients with HVB, HCV and HIV/AIDS should receive dental } \\
\text { treatment in specialized clinics. }\end{array}$ & $345(65.09)$ & $38(7.17)$ & $147(27 \cdot 74)$ \\
\hline $\begin{array}{l}\text { If I found out that my long time patient had HBV, HCV and } \\
\text { HIV/AIDS, I would stop treating him. }\end{array}$ & $74(13.96)$ & $76(14 \cdot 34)$ & $380(71.70)$ \\
\hline $\begin{array}{c}\text { Fear and concern about being infected with HVB, HCV and } \\
\text { HIV/AIDS is one of the reasons to } \\
\text { refuse infected patients. }\end{array}$ & $157(29.62)$ & $165(31.13)$ & $208(39.25)$ \\
\hline $\begin{array}{c}\text { Dentists are anxious about increasing the transmission risk of } \\
\text { the HBV, HCV and HIV/AIDS } \\
\text { while treating them. }\end{array}$ & $201(37.92)$ & $184(34 \cdot 72)$ & $145(27 \cdot 36)$ \\
\hline $\begin{array}{c}\text { Regardless of clinical precautions, there is risk for HIV/AIDS } \\
\text { and hepatitis transmission from } \\
\text { patient to dentist. }\end{array}$ & $490(92.46)$ & $28(5.28)$ & $12(2.26)$ \\
\hline $\begin{array}{l}\text { Regardless of clinical precautions, there is a risk for HIV/AIDS } \\
\text { and hepatitis transmission from dentist to patient. }\end{array}$ & $420(79.24)$ & $23(4 \cdot 34)$ & $87(16.42)$ \\
\hline $\begin{array}{l}\text { Regardless of clinical precautions, there is a risk for HIV/AIDS } \\
\text { and hepatitis transmission from } \\
\text { patient to patient. }\end{array}$ & $488(92.07)$ & $32(6.04)$ & $10(1.89)$ \\
\hline $\begin{array}{l}\text { Dentists have a professional obligation to treat HIV/AIDS } \\
\text { positive patients. }\end{array}$ & $350(66.04)$ & $130(24 \cdot 53)$ & $50(9.43)$ \\
\hline $\begin{array}{c}\text { Infection control measures for preventing HIV/AIDS } \\
\text { transmission should be more than those } \\
\text { for the prevention of HBV and HCV }\end{array}$ & $220(41.51)$ & $85(16.04)$ & $225(42.45)$ \\
\hline $\begin{array}{l}\text { Infection control principles are adequate for preventing the } \\
\text { HBV, HCV and HIV/AIDS transmission. }\end{array}$ & $280(52.83)$ & $82(15 \cdot 47)$ & $168(31.70)$ \\
\hline All patients should be considered potentially infectious. & $402(75.85)$ & $128(24.15)$ & - \\
\hline
\end{tabular}

Table 2. Questions to Assess Attitude Towards HBV, HCV and HIV/AIDS among Dentists (n=530)

study reflected a satisfactory level of knowledge and positive attitude towards HBV, HCV and HIV/AIDS infections amongst dental professionals, however some loopholes were found, indicating that higher level of knowledge of dental professionals plays a vital role in framing the attitudes and practices towards patients with HBV, HCV and HIV/AIDS.

\section{REFERENCES}

1. Data and statistics. (2018, December 18). Retrieved February 01, 2019, from https://www.who.int/hiv/data/en/

2. UNAIDS. (n.d.). Retrieved Februrary 01, 2019, from http://aidsinfo.unaids.org/

3. HIV and AIDS in India. (2019, January 18). Retrieved February 01, 2019, from https://www.avert.org/professionals/hiv-aroundworld/asia-pacific/india

4. India Estimations 2017 - naco.gov.in. (n.d.). Retrieved February 10, 2019, from http://naco.gov.in/sites/default/files/HIV Estimations 2017 Report 1.pdf

5. Rawat N, Mathur N, Rawat K, Mathur M, Chauhan N et al. Prevalence of hepatitis B, hepatitis $C$ and human immunodeficiency virus infection among haemodialysis patients in a tertiary health care centre of Western Rajasthan. Int J Med Sci Public Health 2017;6(4):724-7.

6. Javadi A, Ataei B, Kassaian N, Nokhodian Z, Yaran M. Co-infection of human immunodeficiency virus, hepatitis $C$ and hepatitis $B$ virus among injection drug users in drop in centers. J Res Med Sci 2014;19(1):S17-21. 




Table 3. Questions to Assess Practice Regarding HBV, HCV and HIV/AIDS among Dentists ( $\mathrm{n}=530)$

7. Hosoglu S, Akalin S, Sunbul M, Otkun M, Ozturk R. Occupational Infections Study G. Healthcare workerse compliance with universal precautions in Turkey. Med Hypotheses 2011;77(6):1079-82.

8. Mahboobi N, Porter SR, Karayiannis P, Alavian SM. Dental treatment as a risk factor for hepatitis B and $\mathrm{C}$ viral infection. A review of the recent literature. J Gastrointestin Liver Dis 2013;22(1):79-86. 10.

9. Mohamed N, Saddki N, Yusoff A, Jelani AM. Association among oral symptoms, oral health-related quality of life, and health-related quality of life in a sample of adults living with HIV/AIDS in Malaysia. BMC Oral Health 2017;17(1):119.

10. Bhat M, Ghali P, Deschenes M, Wong P. Hepatitis B and the infected health care worker: public safety at what cost? Can J Gastroenterol 2012;26(5):257-60.

11. Laheij AMGA, Kistler JO, Belibasakis GN, Valimaa H, de Soet JJ. Healthcare-associated viral and bacterial infections in dentistry. J Oral Microbiol 2012;4:10.
12. Dahiya P, Kamal R, Sharma V, Kaur S. "Hepatitis" Prevention and management in dental practice. J Educ Health Promot 2015;4:33.

13.Nor sayani MY, Noor Hassim I. Study on incidence of needle stick injury and factors associated with this problem among medical students. J Occup Health 2003;45(3):172-8.

14. Shojaei S, Jamshidi S, Moghimbeigi A, Mostaghimi N. Evaluation of infection control in dental offices in Hamadan in 2010. Avicenna J Dent Res 2010;3(1):43-52. 15. Moradi Khanghahi B, Jamali Z, Pournaghi Azar F, Naghavi Behzad M, AzamiAghdash S. Knowledge, attitude, practice, and status of infection control among Iranian dentists and dental students: a systematic review. J Dent Res Dent Clin Dent Prospects 2013;7(2):55-60.

16. Wagle $M$, Acharya $G$, Basnet P, Trovik TA. Knowledge about preventive dentistry versus selfreported competence in providing preventive oral 
healthcare - a study among Nepalese dentists. BMC Oral Health 2017;17(1):76.

17. Yadav BK, Rai AK, Agarwal S, Yadav B. Assessment of infection control practice in private dental hospital. Int J Res Med Sci 2017;5(11):4737-42.

18. Bommireddy VS, Pachava S, Sanikommu S, Vinnakota NR, Talluri D et al. Infection control measures among dental practitioners in a Southern state of India: A cross-sectional study. JIAPHD 2016;14(3):302-7.

19. Kadeh H, Saravani S, Golzari P. Knowledge, attitude and practice of dentists towards patients with HIV, Hepatitis B and Hepatitis C infections. Avicenna J Dent Res. 2014;6(1):e21348.

20. Askarian M, Mirzaei K, McLaws M-L. Attitudes, beliefs, and infection control practices of Iranian dentists associated with HIV-positive patients. Am J Infect Control 2006;34(8):530-3.

21. Brailo V, Pelivan I, Skaricic J, Vuletic M, Dulcic N, Cerjan-Letica G. Treating patients with HIV and Hepatitis B and C infections: Croatian dental students' knowledge, attitudes, and risk perceptions. J Dent Educ 2011;75(8):1115-26.

22. Kabir A, Tabatabaei SV, Khaleghi S, Agah S, Faghihi Kashani AH, Moghimi M, et al. Knowledge, attitudes and practice of Iranian medical specialists regarding hepatitis B and C. Hepat Mon 2010;10(3):176-82.
23. Rabiee M, Kazennezhad E. Knowledge and attitude of general dentists regarding HIV and Hepatitis Infections in Rasht. Res Med Educ 2012;4(1):58-67.

24. Kakoei S, Sheibani G, Mohammad Alizadeh S. Awareness and practice of Kerman dentists about Bhepatitis, 2004. Shahid Beheshti Univ Dent J 2007; 25(1):66-72.

25. Leon MP, Rivera A, Chinchilla A. Occupational accidents and knowledge about universal precautions in medica 1 interns of Costa Rica. Antivir Ther 2003;8(1):S517-S8.

26.Hammond JS, Eckes JM, Gomez GA, Cunningham DN. HIV, trauma, and infection control: universal precautions are universally ignored. J Trauma 1990;30(5):555-8.

27. Jafari A, Khami MR, Yazdani R, Mohammadi M. Knowledge and attitude of senior dental students towards HIV/AIDS. J Dental Med 2009;22(4):192-8.

28. Ajami B, Ebrahimi M, Seddighi Z. Evaluation of awareness and behavior of dental students of Mashhad dental school on infection control. J Mashhad Dent School 2009;33(1):53-62.

29. Burke FJT, Wilson NHF, Shaw WC, Cheung SW. Glove use by orthodontists: results of a survey in England and Wales. Eur J Orthod 1992;14(3):246-51.

30. Salgam N, Medine A, Sarikaya N. Evaluation of infection-control practices by orthodontists in Turkey. Quintessence Int 2004;35(1):61-7.

Source of support: Nil, Conflict of interest: None declared

Cite this article as:

Yadav OP, Yadav D, Joshi A, Asopa SJ, Ahmed N, Panwar M. Dentists' Knowledge, Attitudes and Practices Regarding Hepatitis B, C and Human Immunodeficiency Virus/ Acquired Immunodeficiency Syndrome in Northeast Part of Rajasthan. Int Healthc Res J. 2019;3(2):87-92. doi: 10.26440/IHRJ/0302.05.521083

\section{AUTHOR AFFILIATIONS:}

MDS, Research Scientist (Medical), Department of Microbiology, Sardar Patel Medical College, Bikaner, Rajasthan

MBBS, Junior Resident, Department of Dermatology, Venereology \& Leprosy, Govt. Medical College, Bhilwara

BDS, Lecturer, Department of Conservative \& Endodontics, Rajasthan Dental College \& Hospital, Jaipur

MDS, Reader, Department of Prosthodontics, Rajasthan Dental College \& Hospital, Jaipur

MDS, Senior Resident, Department of Dentistry, Sardar Patel Medical College, Bikaner, Rajasthan

PG Resident, Department of Public Health Dentistry, Rajasthan Dental College \& Hospital, Jaipur

Corresponding Author's Address:

Dr. Om Prakash Yadav

A-44, Ashok Nagar

Purani Chungi, Ajmer Road

Jaipur, Rajasthan, India.

Pin Code: 302019
For article enquiry/author contact details, e-mail at: editor.ihrj@gmail.com,editor@ihrjournal.com 